\title{
21
}

\section{The Prehistoric House: A Missing Factor in Southeast Asia}

\author{
Charles Higham
}

Excavations in Mainland Southeast Asia have yet to reveal a single complete house plan, yet the potential of residential archaeology to illuminate social change, particularly when human burials are found in association, is emphasised by recent research in other parts of the world. Non Ban Jak is a late Iron Age town in the Mun Valley of Northeast Thailand. Excavations over the past four years have revealed a sequence of domestic architecture, in which the dead were interred within houses. This paper explores the potential of this site to examine social organisation during a period when an agricultural revolution stimulated the rise of inequality at the threshold of early state formation.

\section{Introduction}

The prehistoric record of Southeast Asia from Neolithic settlement to the foundation of the first states suffers from the absence of information on where people lived. The lack of a single house plan might conceivably reflect the use of piles to raise buildings above the ground level. This should result in posthole patterns in the form of individual buildings. However, the decay of wooden posts and their replacement over time are likely to result in a palimpsest of postholes with no clear structure. Although bronze models in the Dian chiefdom of Yunnan, and images on Dong Son drums show houses raised on posts, this does not imply that it was a universal prehistoric practice. As a consequence of the dearth in archaeological research in Southeast Asia dedicated to the investigation of settlement patterning, construction techniques and function, assessments of social organisation and change rely heavily on mortuary data.

The recent literature on residential archaeology elsewhere reveals how much we are missing in Southeast Asia. Returning after an interval of over 50 years to the subject of my doctoral dissertation, the Swiss lake villages (Higham 1966), I marvel at the social information that is now available. One key, as always, is chronology, and with the precision of dendrochronology, the construction of individual houses can be dated by the year. Thus houses at Neolithic Arbon Bleiche 3 on the southern shore of Lake Constance were constructed between 5326-5334 BP (Eberschweiler et al. 2006). Houses were placed in neat rows, and each measured little more than $8 \mathrm{~m}$ by $4 \mathrm{~m}$. New buildings constructed within a span of just eight years indicate not a growing population so much as the arrival of new members of the community from elsewhere. Ebersbach has described 'Another thrilling result of detailed spatial analyses of all kinds of remains is the 
observation that there are quite a lot of settlements with multi-ethnic compositions of the inhabitants' (2013: 293). Thus, again at Arbon Bleiche 3, neighbouring houses revealed distinct ceramic styles, fishing techniques and diets of the occupants (De Capitani and Leuzinger 1998; De Capitani et al. 2002). Houses did not last for long. An oak post sunk into a wet substrate has a lifespan of about six years. Hence, villages were not long lived and people moved to a new settlement several times in a lifetime. The snapshot of Arbon Bleiche, with intimate details of daily life, is but one component of millennia of social change on the alpine foreland.

Human remains are very rare in these sites, and often absent. At the Linearbandkeramik (LBK) site of Karsdorf in Central Germany, however, the conjunction of Neolithic houses with human burials has seen the deployment of aDNA to distinguish between indigenous hunter-gatherer and incoming farmer ancestry, strontium isotopes to identify those raised elsewhere, and light stable isotopes to analyse diets. One major advantage of these LBK sites is that one can excavate extensively, because the stratigraphic build up is so shallow. At Karsdorf, the excavation uncovered 51 times the area of my fieldwork at Ban Non Wat or Non Ban Jak, and 180 times that of Khok Phanom Di. Thus, 24 longhouses were mapped, set out in rows, the largest measuring $24 \mathrm{~m}$ by $8 \mathrm{~m}$ (Brandt et al. 2014). The aDNA variation indicates several maternal lineages, and close affinity with other LBK sites. A small proportion of the haplotypes evidence descent from the indigenous hunter-gatherers, but the majority reveal demic diffusion ultimately from the Near East. If only DNA survived so well in Southeast Asia. Strontium isotopes have identified two groups, which probably farmed in different soils accessible from the settlement. It is also concluded that the community was patrilocal, with women entering it from elsewhere.

\section{The house in Southeast Asia}

White and Eyre (2010) have investigated the potential of residential archaeology in Southeast Asia by suggesting that published reports on the few excavated sites in Northeast Thailand have missed a vital point: that the dead were interred in residences. Being reliant more on water than the soil for growth and maturity, rice cultivation encourages permanent settlement and sites like Ban Non Wat and Ban Chiang were occupied, and the cultural deposits accumulated, for millennia. By dovetailing long-term settlement with burial within or closely associated with domestic residences, White and Eyre argued that in Northeast Thailand house societies involved long-term occupation by heterarchic, non-violent supravillage affiliative social groupings. The problem with this proposal is the lack of archaeological evidence for houses (Higham 2015).

This void is being filled by Bellwood's fieldwork in southern Vietnam (Bellwood et al. 2013; Oxenham et al. 2015), where Neolithic Rach Nui, An Son and Loc Giang reveal superimposed floors associated with postholes that, with more extensive excavations, would doubtless illuminate house plans. These new excavation results are a reminder of a rectangular clay structure comprising a floor and walls representing the sixth mortuary phase at Khok Phanom Di. Containing three inhumation graves dating to about $3600 \mathrm{BP}$, it has been interpreted as a burial structure rather than part of a residential house (Higham and Bannanurag 1990). In 1994, excavations covering $405 \mathrm{~m}^{2}$ at Bưng Bạc in Bà Rịa - Vũng Tàu Province, Southern Vietnam, uncovered the wooden piles that raised houses above the flood level, together with the planks of a wooden floor, expertly joined together with the use of dowels (Bùi et al. 2012). Structural remains dating to the late Iron Age in Northeast Thailand have also been known for some time. At Non Muang Kao, O'Reilly (1997) traced superimposed clay floors and wall foundations associated with human burials. The deposits were so hard, however, that only a very small test square was involved, and no plans of rooms, let alone houses, were mapped. Disturbed clay floors in proximity to human graves dating to the Iron Age have been identified at the nearby sites of Ban Non Wat and Noen U-Loke 
(Higham and Kijngam 2012). The same pattern is also seen in Central Thailand during the Iron Age (Higham and Rispoli 2014). There is clearly a need to open very large areas of the Neolithic sites of Southern Vietnam, and Iron Age settlements of the Mun Valley in order to realise the potential of residential archaeology.

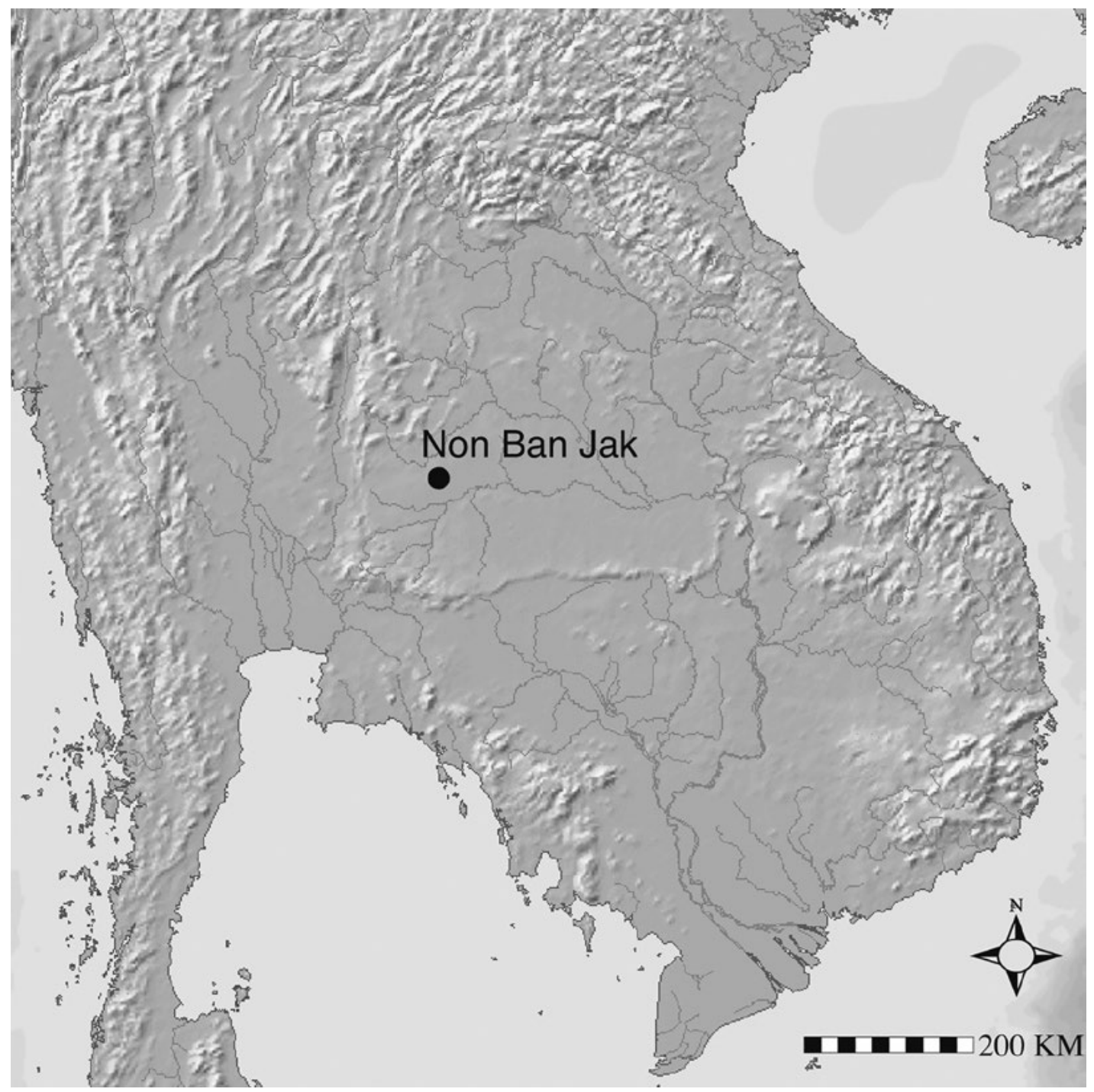

Figure 21.1 Location of Non Ban Jak in Northeast Thailand.

Source: C. Higham.

\section{Non Ban Jak}

Non Ban Jak is one of the moated, Iron Age sites that cluster densely in the upper Mun Valley on the Khorat Plateau (Figure 21.1). It covers an area of $360 \mathrm{~m}$ by $170 \mathrm{~m}$, and is surrounded by two broad moats demarcated by banks. There is a western and an eastern mound, separated by a low-lying area that crosses the centre of the site (Figure 21.2). The first season of excavations opened an area measuring $8 \mathrm{~m}^{2}$ on the eastern mound, while the following three seasons have uncovered $35 \mathrm{~m}$ by $10 \mathrm{~m}$ that began in the low-lying area and climbed onto the western mound. The radiocarbon determinations place moat construction in the fourth to fifth centuries AD 
(McGrath and Boyd 2001). Over $40 \mathrm{C}^{14}$ dates from rice, human bone and shells from occupation and mortuary contexts indicate that initial settlement took place in the third to fourth centuries $\mathrm{AD}$. There are four mortuary phases that date from the fourth to at least the sixth centuries $\mathrm{AD}$, with a late occupation context that incorporated Dvaravati-style pottery vessels and other artefacts. This phase ended within the period 1250-1130 BP. Non Ban Jak therefore falls into the fourth and final phase of the Iron Age in the upper Mun Valley.

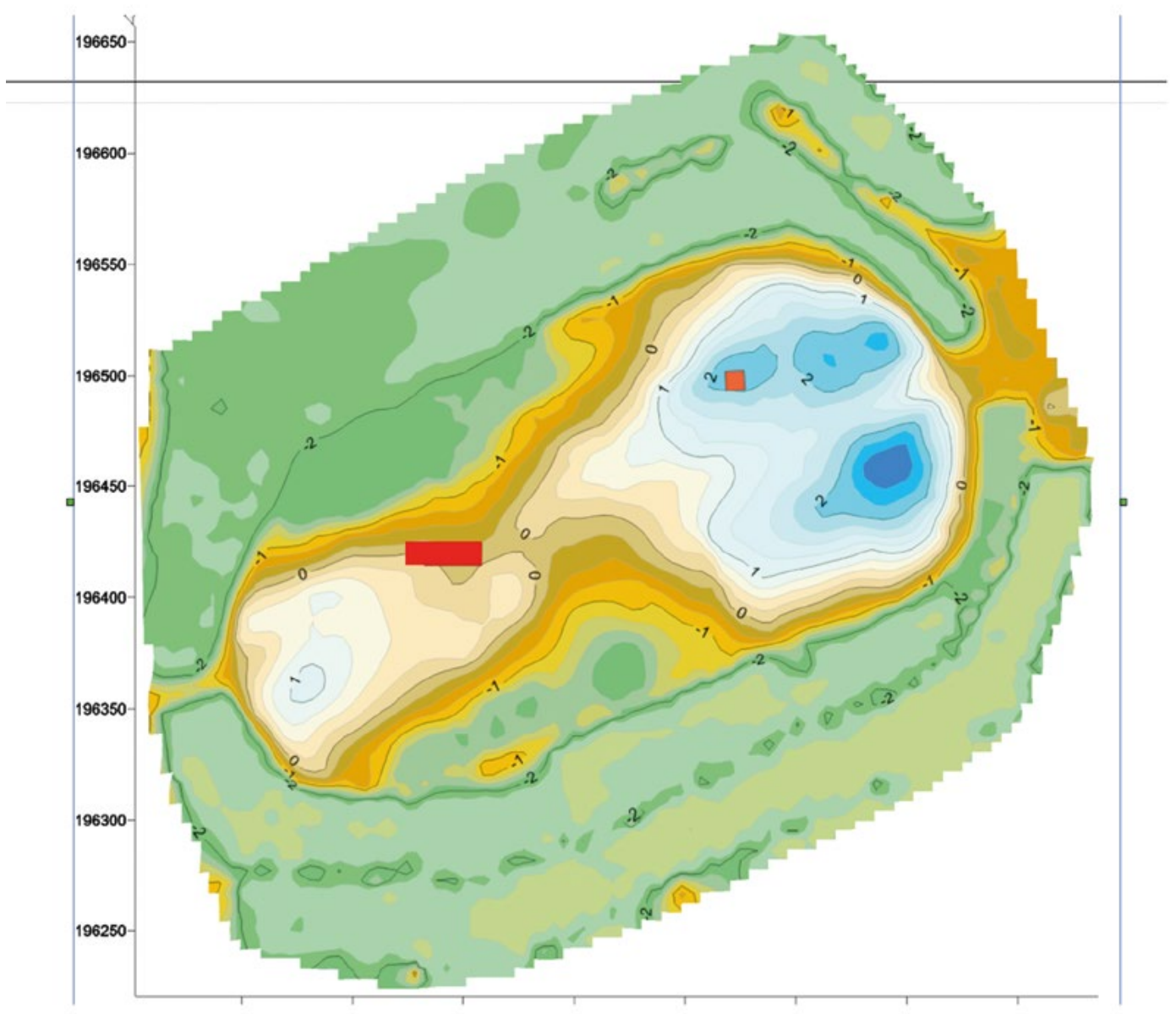

Figure 21.2 Plan of Non Ban Jak, showing the two areas excavated.

Source: Nigel Chang.

Early in the first season, we realised that Non Ban Jak had the potential for engaging with settlement archaeology. I took photographs of the surface of the excavated area at the end of each day, and downloaded and examined them in the evening. After uncovering a series of Early Historic Period Dvaravati pits filled with restorable ceramic vessels, we cleaned the newly exposed surface. The images revealed the faint traces of parallel white lines that turned right angles (Figure 21.3). Over the ensuing days, these were revealed as walls made from white clay, that enclosed rooms with smoothed clay floors. The walls contained equidistant postholes, which we presumed were structural wall supports. 


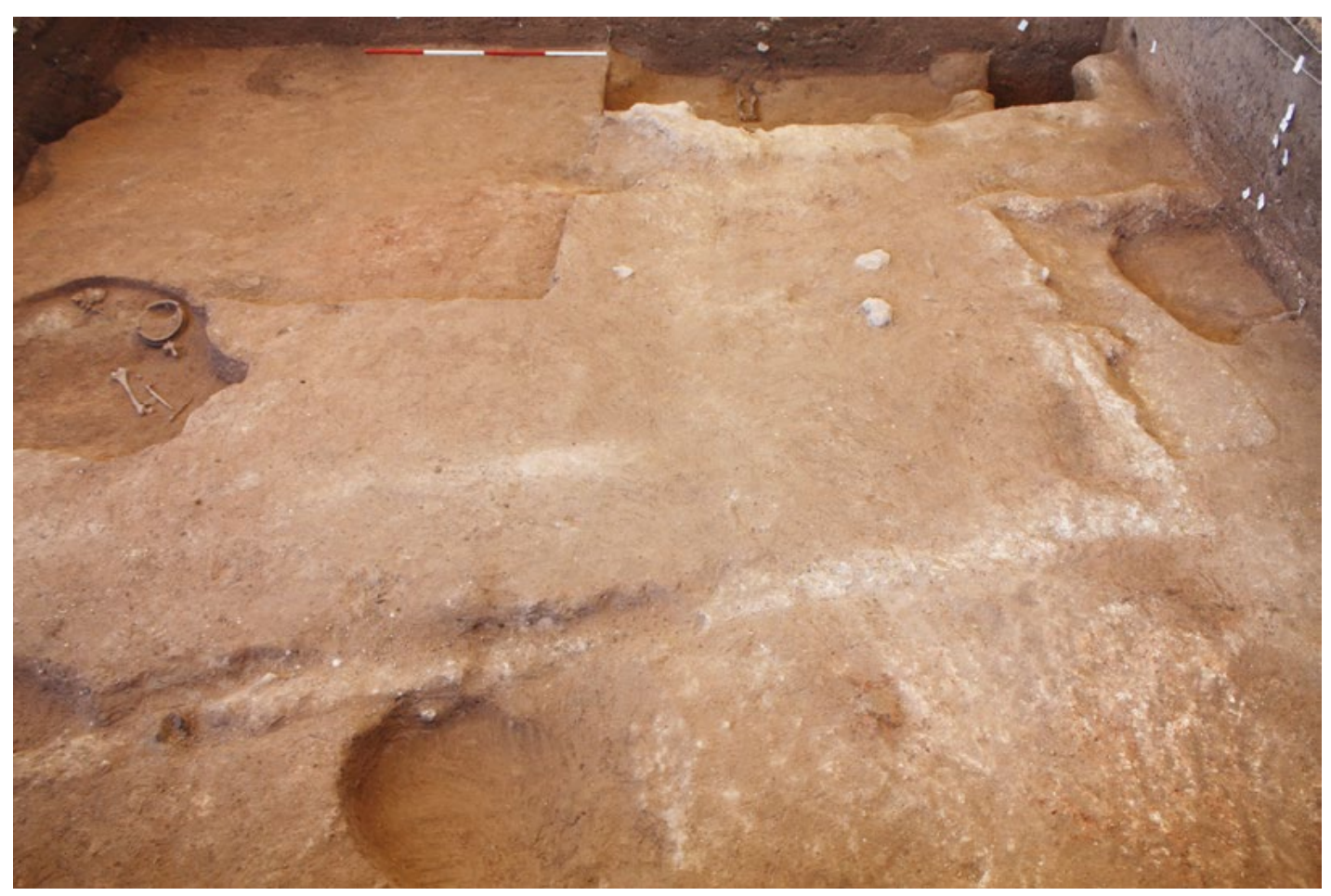

Figure 21.3 The first inkling that residential structures would be found at Non Ban Jak came as white walls and a floor were revealed.

Source: C. Higham.

Our excavation on the eastern mound reached the natural substrate at a depth of $4 \mathrm{~m}$ below the present surface. We identified multiple building phases in which the house walls followed the same orientation, although the quality of the buildings improved over time. Manufacturing activities were undertaken in this residential area. The lowest context involved a circular ceramic kiln containing seven pots and a socketed iron ploughshare, covered by a thick layer of fragmented burnt clay that incorporated impressions of wooden supports. Kiln rake out included broken Phimai Black vessels and burnt clay, as well as carbonised rice grains. Three infant jar burials were found beside this kiln.

Houses were built over the kiln, seen in thin laterite and clay wall foundations of rooms about $3 \mathrm{~m}$ wide (Figure 21.4). There is a surviving area of burnt clay floor, incorporating an upright ceramic vessel, and many rice grains. The northwest part of this structure comprised a series of parallel, semi-circular impressions on the clay floor, which are probably a split bamboo foundation that end abruptly and in unison, as if they had reached the edge of an internal room within the building. A kiln lay parallel and close to the eastern wall. It contained one very large pottery vessel as well as the clay daub cover. The charred wooden wall foundations and incinerated clay floors indicate that the adjacent building had been burnt, not surprising given its close proximity to a kiln. 


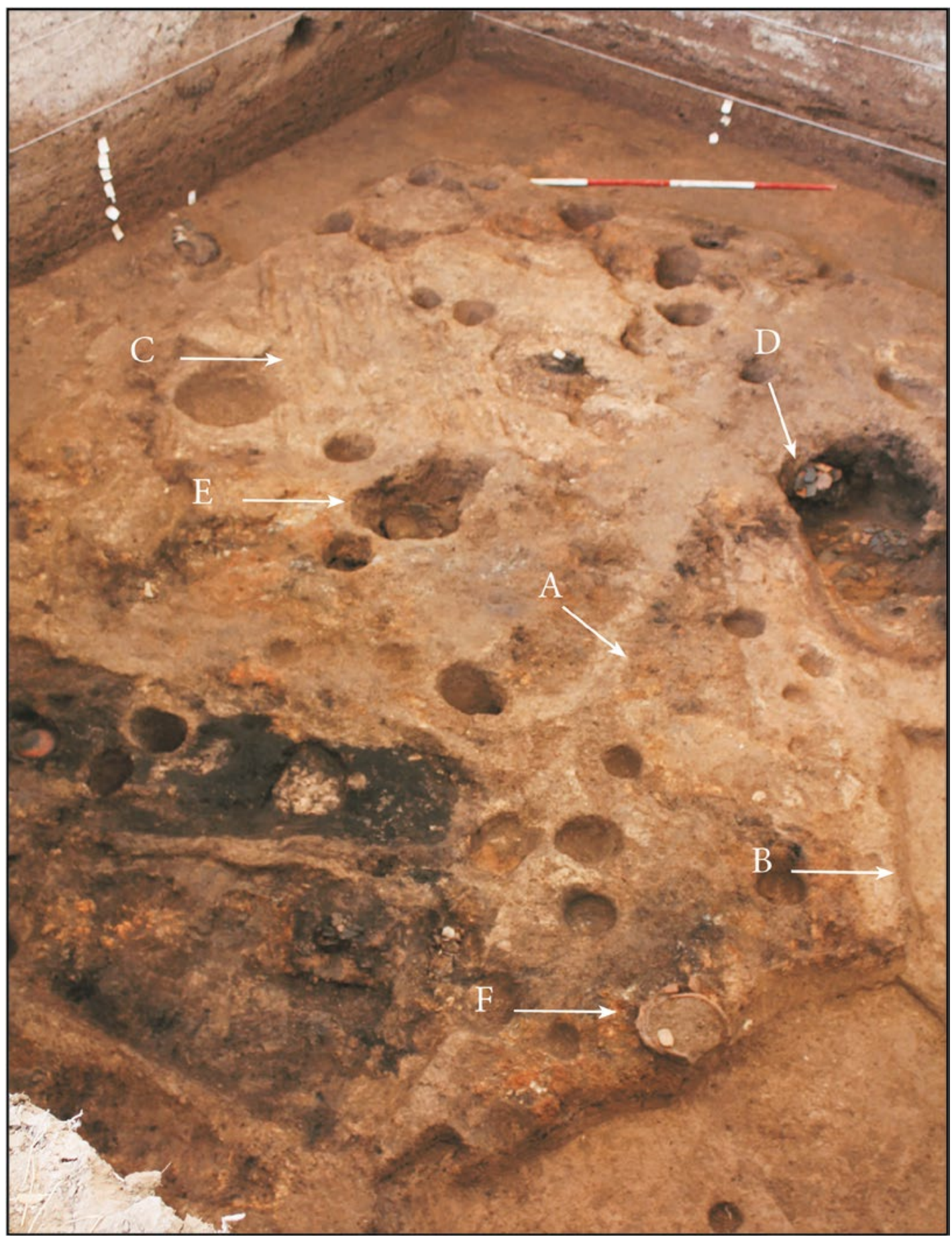

Figure 21.4 The surface of layer 5.2 in the eastern square showing superimposed buildings. A. is the eastern wall of the later structure. B. is the eastern wall of the earlier building, which was laid out on a different orientation. C. is the clay floor bearing what are probably bamboo impressions. D. is a ceramic kiln laid out on the same orientation as the earlier of the two structures. E. is an infant burial cut through the floor, and F. is the kitchen area. In the foreground, one can see the charcoal, ash and burnt daub of the floors and collapsed walls of the earlier building.

Source: C. Higham. 
The building was replaced, but on a slightly different orientation, about $10^{\circ}$ west of north. To the south, lay a series of pits, two of which contained intact Phimai Black ceramic vessels. There was much evidence for burning. Within, there were thin subdivisions of laterite marked by postholes that may have supported furniture or other internal features. The clay or laterite floors had been subjected to considerable heat when the structure was burnt. These floors contained concentrations of carbonised rice and broken ceramic vessels. A clay-lined hearth sitting on an incinerated kitchen floor still contained a cooking vessel and mounds of rice grains. The skeleton of a rat lay adjacent to the southern exterior wall. The structure as a whole measured $3.40 \mathrm{~m}$ by $6.40 \mathrm{~m}$, although the walls proceeded beyond the excavation square. A laterite floor in the centre of the largest interior room sealed an oval pit that contained an infant jar burial. Since this grave also cut through an earlier laterite floor, it must date to the period when the building was in use. To the west of this building there is a clay wall foundation lying on the same orientation. A narrow gap, perhaps a lane, separates the two. The plan reveals three houses all on the same orientation, each divided from its neighbour by a narrow thoroughfare. The potential for tracing the plan of the initial Iron Age residential area is self-evident.

Following the burning of the early houses, the sequence on the eastern mound continued with the construction of new buildings, on the same orientation but with thicker wall foundations. These enclosed a solid clay floor containing a rectangular cutting of mottled fill surrounded by rows of postholes. This looked very like a further grave cut but, when opened, there were no human remains. The wall to the north of this floor had been cut into with the creation of a grave. Another structure on the eastern edge of the excavation comprised a wall foundation of white clay with a lining of grey clay enclosing superimposed grey or red clay floors and two hearths. A third ash-filled hearth was found towards the north of the room. It is evident that this room was occupied over such a period of time that re-flooring was periodically necessary.

Further superimposed floors and walls evidence yet another construction phase, but on this occasion they were accompanied by a series of clay-lined furnaces. The presence of iron slag suggests that these were smithing furnaces. A burnt red clay floor lies to the northeast of this concentration. In the northwestern quadrant, a mutilated clay floor lies adjacent to a clay wall foundation, suggesting that there was a residential complex in this part of the site. A laterite wall foundation runs just a few degrees west of due north in the central part of the square, and several postholes were dug from this depth.

Lower layer 2 incorporated a series of walls divided by town lanes or walkways. One room contained the burials of an adult, a child and an infant (Figure 21.5). The adult grave lies within two parallel rows of large postholes. A hearth is found in the southern half of this room. Mouth to mouth Phimai Black pottery vessels were placed in the three intact corners. There are also some broken pots in the southern part of the chamber. This room is separated from the building to the southeast by a narrow lane that, unlike the rooms themselves, contained occupation debris dominated by Iron Age potsherds. No further burials were found in these rooms, but a set of hearths was present in the southeastern corner room. It is possible that this complex represents a domestic dwelling incorporating a mortuary chamber.

The walls of this mortuary room were solidly built. The foundations were up to $80 \mathrm{~cm}$ wide, and comprise white clay of the sort that would have been available during the excavation of the moats to form the retaining banks that ring the site. The interior edge of the foundation contains a line of postholes for timbers that would have supported the walls. A narrow channel running between the posts and the wall may well have been the foundation for the interior lining of the chamber. The floor abutted the wall and one of the sets of mouth to mouth Phimai Black pots was lodged hard against the latter, sitting on the surface of the clay floor through which a grave had been cut. 


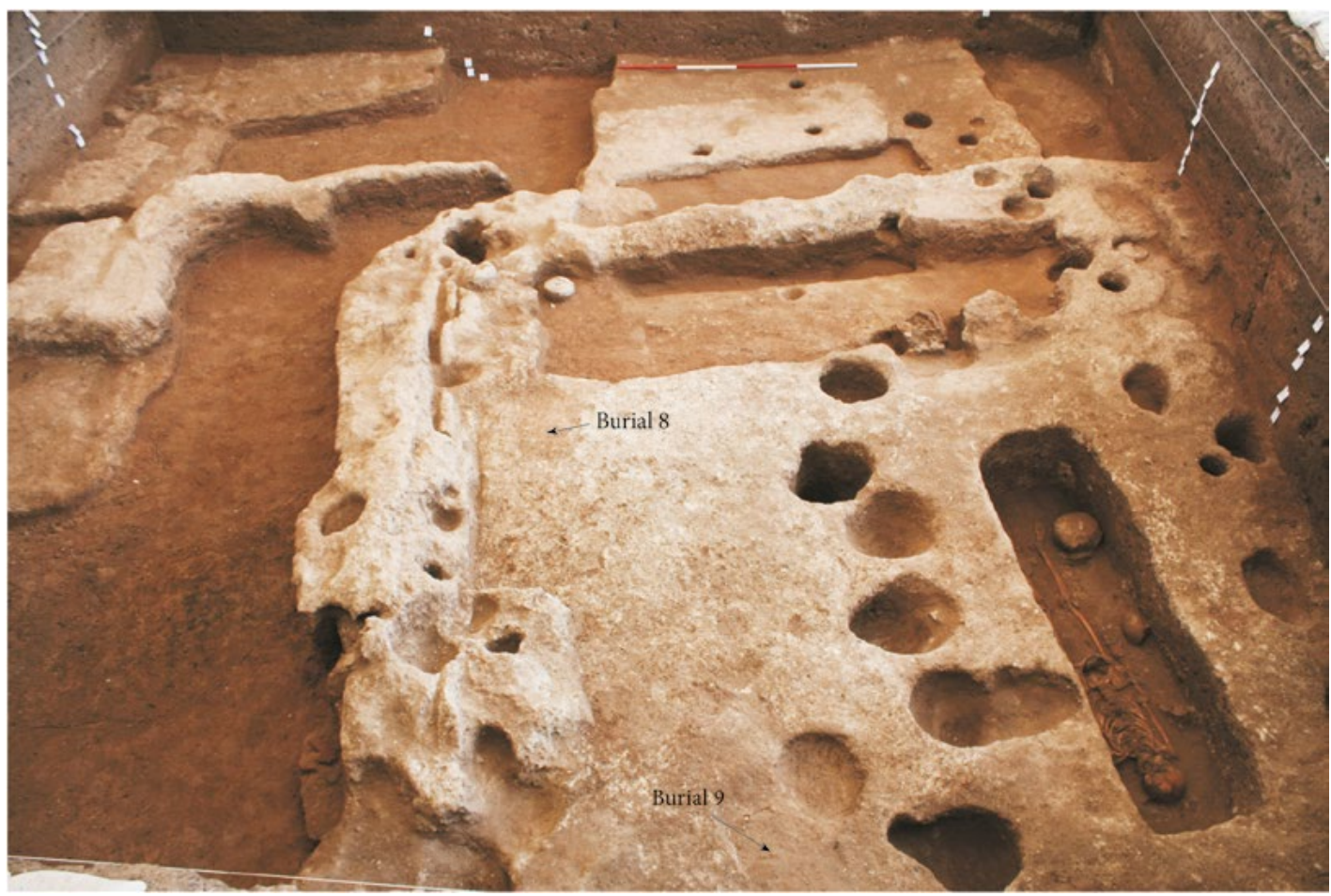

Figure 21.5 Layer 2 in the eastern square, showing the mortuary chamber containing the graves of an adult, a child and an infant. A rectangular clay floor can be seen in the distance, cut by a rectangular pit. A lane between two buildings runs north-south on the left of the photograph before turning a right angle.

Source: C. Higham.

\section{The eastern mound: Summary}

Although only measuring $8 \mathrm{~m}$ by $8 \mathrm{~m}$, the area opened on the eastern mound provided, for the first time in the Upper Mun Valley, insight into the architecture and layout of an Iron Age town, and the close relationship between residential, mortuary and manufacturing activities. Over a period of at least three centuries, houses were frequently rebuilt on the same orientation. Earlier houses were constructed with thin walls of clay or laterite, and floors of clay, fortified with bamboo foundations. A kitchen still contained a cooking vessel on its stove, and masses of rice grains on the floor, as if consumed in a conflagration. Infants had been interred within the houses, contained in ceramic vessels. These early houses were contemporary with pottery kilns, suggesting that the fashioning and firing of pots was a domestic rather than a specialised industry. The same might apply to the evidence for iron smithing being pursued in a residential part of this site. The pots remaining in these kilns had been used for both domestic and mortuary purposes.

Continuity of occupation is seen in the regular rebuilding of houses that over time became much more solidly constructed. This culminated in the final occupation phase, when walls reached a thickness of $80 \mathrm{~cm}$. One room belonging to this phase contained three graves, each cut through a solid clay floor. Lidded pottery vessels had been placed in at least three of the four corners. Pots of this form were often found near inhumation graves, and this conjunction suggests that they were placed for a ritual purpose. 


\section{The western mound}

The excavation on the western mound covered an area of $35 \mathrm{~m}$ by $10 \mathrm{~m}$ (Figure 21.6). Squares $\mathrm{X}$ and $\mathrm{Y}$ have little evidence for occupation, but early burials cluster on the laterite substrate. As one progresses in a westerly direction, the first structural evidence was identified in the form of a white clay wall foundation. Beyond this, in squares $A A$ to $\mathrm{DD}$, superimposed house floors and walls are found, together with human burials within these structures, and on the same orientation as the walls.

The accumulation of occupation and mortuary remains reached a maximum depth of approximately $1.8 \mathrm{~m}$ but in some parts of the site, little over a metre. Excavation stopped when the laterite bedrock was reached. Above this, there was a variable deposition of two naturally deposited silt layers. The earliest burial was found under this material. Occupation and mortuary remains accumulated above these, to the base of the cultivated topsoil. The latest clay floors and burials were thus encountered at a depth of only $15-20 \mathrm{~cm}$. This cultural sequence has been divided into four phases on the basis of slight changes in the colour and texture of the deposits. This lack of differentiation reflects the fact that, according to the typology of the ceramics recovered, and the radiocarbon determinations, this part of the site was occupied for only a few centuries. A Bayesian analysis of the dates suggests that the initial occupation took place in the fourth century $\mathrm{AD}$. The transition to layer 3 took place within the period 1490-1420 BP. Layer 2 is only marginally later. The final occupation, which incorporates historic as well as late prehistoric ceramics, ended in the eighth century $\mathrm{AD}$.

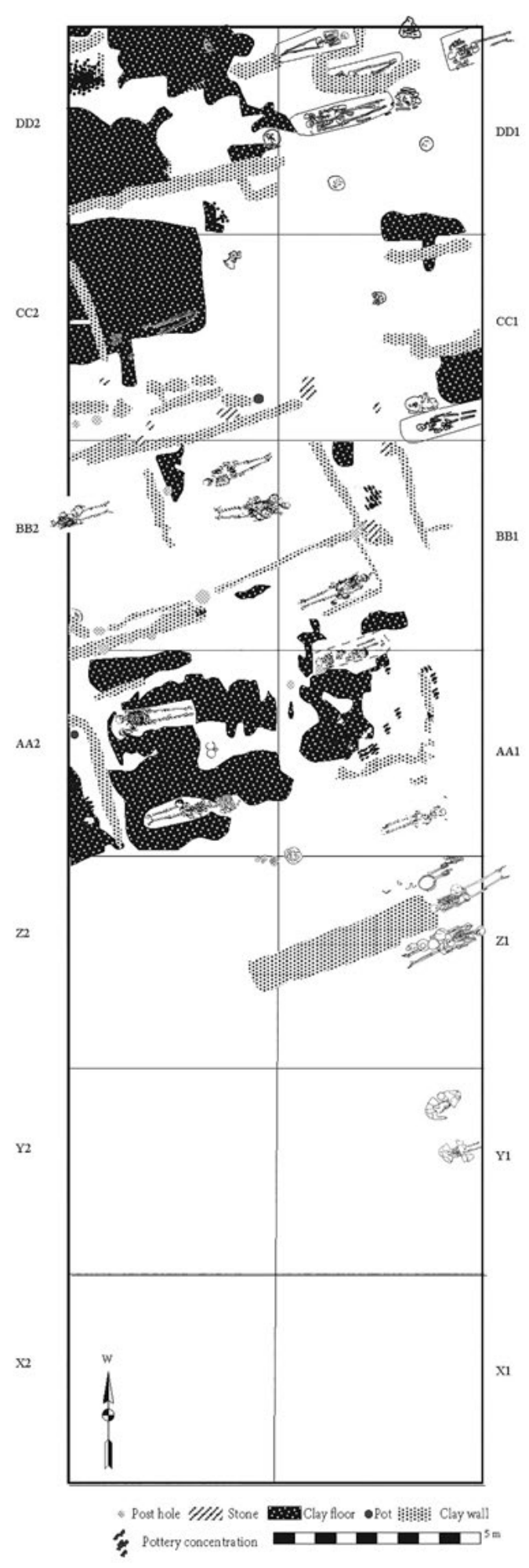

Figure 21.6 The plan of the western mound excavation showing unit numbers, and the layout of graves and structures during the third mortuary phase.

Source: C. Higham. 


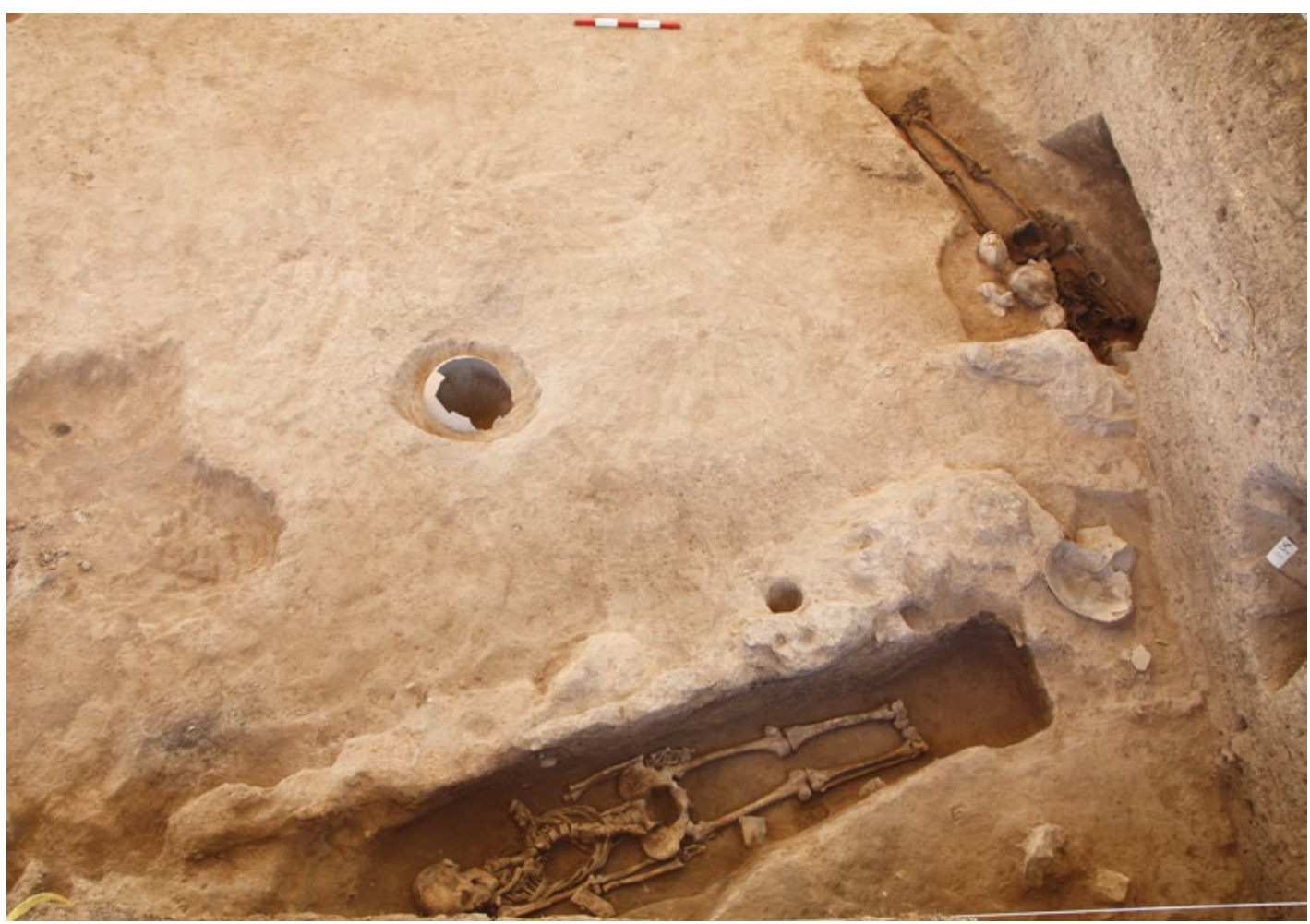

Figure 21.7 The western square included a wall ending with a large stone against which an infant jar burial had been interred. An adult burial had been cut through the floor and a second lay at right angles to the right. Another infant burial jar is seen in the centre of the image.

Source: C. Higham.

As with the eastern mound, superimposed house walls and floors were traced, all on the same orientation. However, at no stage were the walls as impressively finished as those in the later phases to the east. The conjunction between structures and burials is, however, equally clear. Burial 134 lay hard up against a wall, the grave having severed a floor littered with Phimai Black potsherds (Figure 21.7). The wall typically ended with a large stone foundation, against which an infant jar burial had been wedged. Burial 136 was positioned at right angles to Burial 134, and was cut through the floor to the south of the wall. Burial 137 was also placed at right angles to Burial 134, but it had been seriously disturbed. Beyond and to the south lay, on the same orientation, the complete grave of an infant. A further infant jar burial completed this nucleus of graves. This same occupation layer incorporated concentrations of hearths. Some were claylined, and contained deposits of ash, while others comprised a ring of stones, often with a broken pot still in place (Figure 21.8). The pots in question were of a form still used for cooking rice. Carbonised rice grains were found in one such pot that had been used as a mortuary offering.

This domestic and mortuary activity was associated with the firing of pottery vessels. One large ceramic kiln, dug down to the surface of the laterite substrate, contained a complete vessel, but lacked the concentration of rice grains found in three deep pits containing fractured pottery vessels and much charcoal and burnt daub that were encountered further to the west. It is not easy to explain the remarkable quantities of rice grains found in these but, nevertheless, the most likely interpretation is that they were also kilns. A pattern noted in the eastern mound is repeated, in that two of these kilns had infant jar burials at their uppermost edges. 

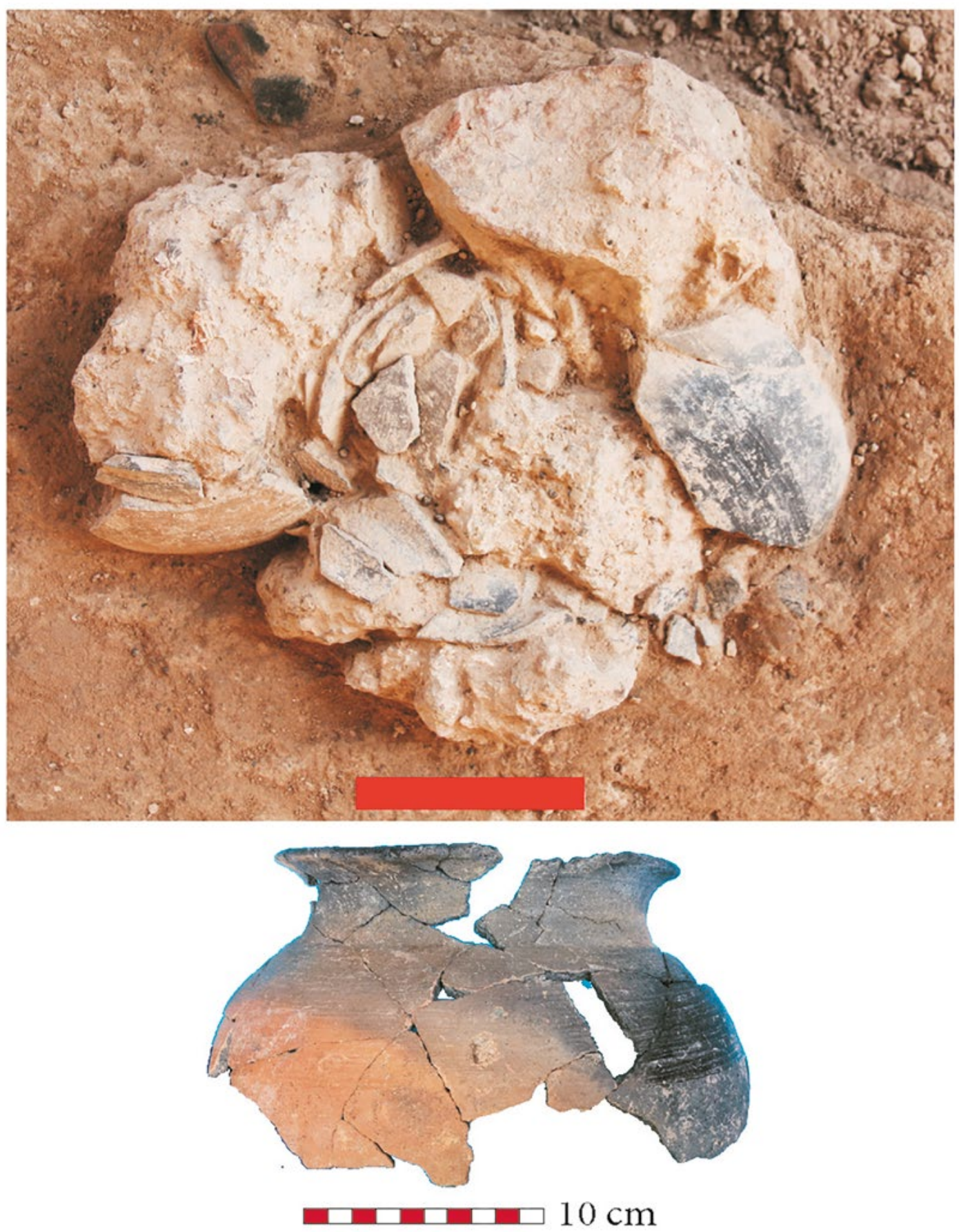

Figure 21.8 Domestic activity associated with the houses is seen in the many cooking hearths. In this instance, a set of stones surrounds ash and a broken cooking vessel. Source: C. Higham.

Succeeding walls and floors are distributed across the excavated area, with the exception of the eastern margin. One structure incorporated a clay floor through which three burials had been cut, namely two adults and an infant (Figure 21.9). Further west, a wall and associated floors were linked to Burial 120, which was positioned at the end of the wall, and was cut through and slightly lower than the floor. Two hearths were found to the north of this grave. The tall male was interred with an impressive range of jewellery including gold earrings decorated by repoussé. 
This context preceded a further a system of walls and floors, through which burials were inserted. There is also evidence for occupation in the form of pits and concentrations of pottery sherds. Burial 72 was cut through a floor, and within the corner of a clay wall. It comprises part of a row with two other burials found on the same orientation.

The postholes embedded in the walls were presumably supports for the wattle and daub superstructure. The plan suggests the presence of lanes within the settlement. In squares CC and $\mathrm{DD}$, walls formed rectangular rooms with large stones placed strategically where walls ended or turned at right angles (Figure 21.7). Burial 114 at the extreme western edge of the excavated area lay within the right-angled bend of two such walls. Three radiocarbon determinations suggest that it dates to the fifth century AD, or perhaps slightly later. Structural remains and burials continued right to the present ground surface, with the latest burials being contemporary with pottery vessels characteristic of the Dvaravati Early Historic period.

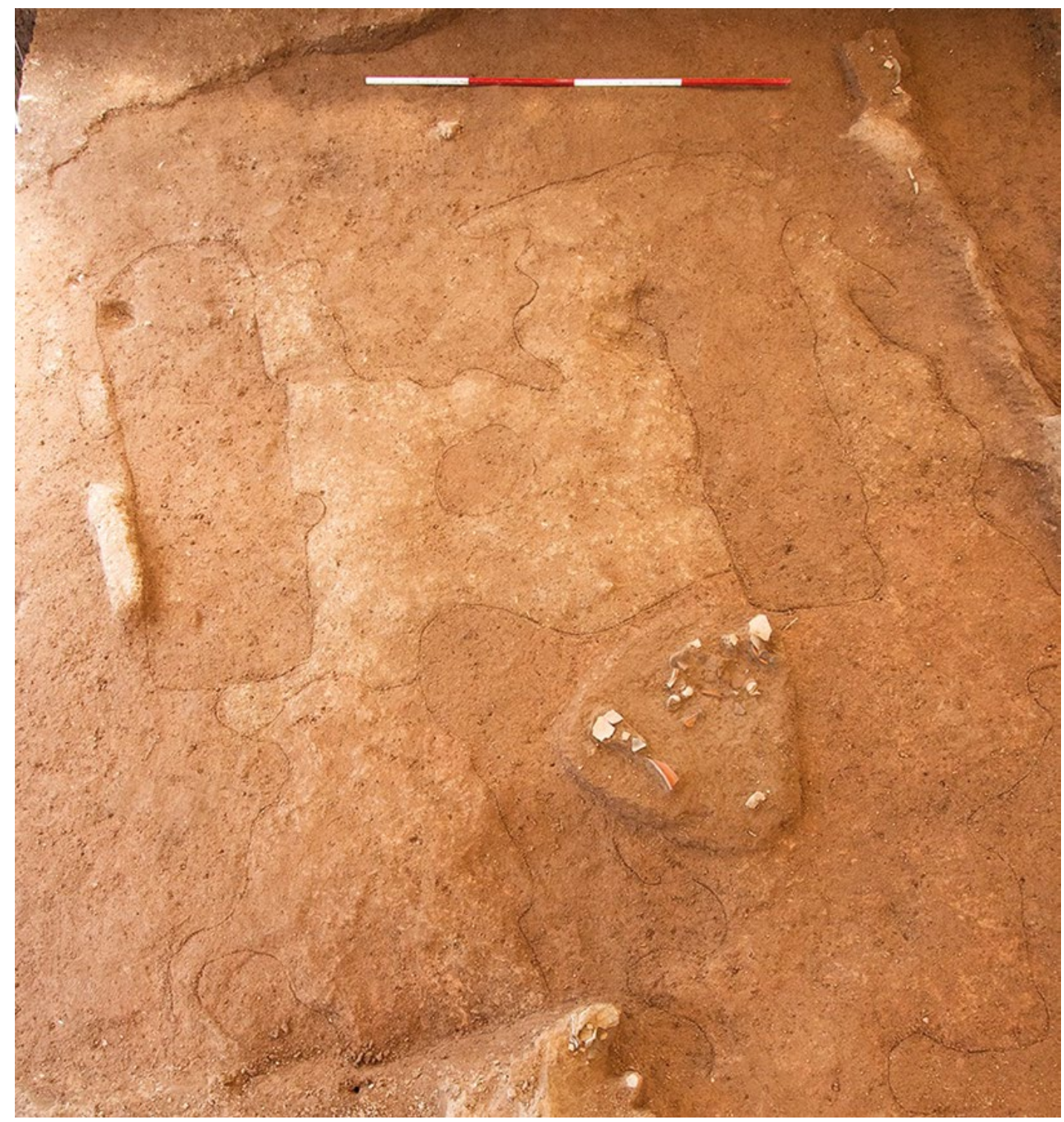

Figure 21.9 Three graves were cut through the clay floor of this walled chamber in the western square.

Source: N. Chang. 


\section{The people of the western mound}

Apart from the first of the four mortuary phases (MP) identified on the western mound, the dead were interred in a close relationship with the walls and floors. The MP1 burials were concentrated in the eastern part of the excavated area. Six were male, two female and one could not be assigned a sex. There are 14 infant burials representing 60 per cent of the sample, high even for the prehistoric period in Southeast Asia. The adults were interred on a northwest or southeast orientation, save for one, buried with the head directed to the east. Ornaments include agate beads and pendants, glass beads, one bimetallic iron and bronze ring, together with bronze finger and toe rings and bangles and an anklet. No individual was accompanied by more than three pottery vessels. Several had a bivalve shell. Most infants were buried in mortuary vessels. The range of offerings matched that for the adults in terms of bronze ornaments, except that an infant wore three bronze belts. There was also a marine shell pendant and an iron bangle.

Mortuary Phase 2 burials were concentrated in the central and western parts of the excavated area. There are 18 adults and 27 infants, the latter again comprising 60 per cent of the sample. Eight males have been identified, five females and five adults of unknown sex. Although rare, the first iron sickles, knives and spears were found in mortuary contexts. The ornaments worn by adults continued to include bronze rings and bangles, glass beads, and beads and pendants of agate. One man was interred with two spindle whorls. There were never more than three pottery vessels in any one adult burial. Infants had a wider range of mortuary offerings. Ornaments other than bronze rings, bangles and anklets included beads of gold, carnelian, glass and agate. One infant was associated with five pots, another with four. There were also bivalve shells, bimetallic iron and bronze rings and bangles and, with Burial 104, a bird's egg.

Mortuary Phase 3 burials are found in three clear rows that comprise the graves of men, women and infants. Ten men are represented, five women and one adult of unknown sex. There are also the graves of 18 infants, meaning that they comprise 53 per cent of the mortuary population. When burials are superimposed over the distribution of walls and floors, clear relationships are observed (Figure 21.6). There was a tangible increase in the range and quantity of mortuary offerings. Bronzes now included the two bronze belts, worn by a man, identical to those recovered from men buried at the nearby site of Noen U-Loke. There were also finger rings, bangles and earrings. Iron knives and sickles were more numerous than during MP2. One young man wore a gold finger ring another had earrings of gold. There were also bimetallic iron and bronze rings, and the man with the gold earrings also wore beads and a pendant of agate. Infants were also wealthier than hitherto, with up to five ceramic vessels, and bronze toe, ear and finger rings and bangles.

Mortuary Phase 4 burials were found just below the surface of the excavated area, and chronologically extended into the Early Historic period. However, the mortuary rituals and associated offerings remain virtually unchanged from MP3. Some burials were thus clearly related to floors and walls. Four men are represented, three women and four indeterminate adults, against five infants. The proportion of infants fell to 31 per cent of this sample. Up to four pots were found with adults. There were also gold earrings, an agate pendant and bronze ear and finger rings. Iron sickles and knives were found, along with a machete, a spear and a point. Infants were found with up to four pots, bronze earrings, bangles and glass beads.

The pseudomorphs of rice grains and fabric on the surface of iron mortuary offerings suggest that the dead were interred clothed, in a grave containing rice. There is also regularity to the mortuary offerings, seen in the placement of iron knives and sickles. Pottery vessels also follow a common theme, with at least one pot form compatible with cooking, and a bowl suited for eating therefrom. Compared with the Iron Age 3 cemetery at Noen U-Loke, however, the mortuary 
offerings are modest, and much more akin to those of Iron Age 4 at that site. The impression is that the western mound population included individuals who worked in the rice fields at harvest time. Some were proficient potters following a domestic mode of production. Spindle whorls evidence a weaving industry, and iron forging was also undertaken. Exotic ornaments of bronze, carnelian, agate, lead and gold, however, indicate participation in a wide exchange network.

\section{Conclusions}

Fieldwork at Non Ban Jak and the analysis of all the material and biological data are progressing, and the full interpretation of this Iron Age settlement is for the future. At present, it is easier to review the potential of the site than to draw early conclusions. A key point is the excellent preservation of the human remains. This encourages optimism when the time comes to consider evidence for demography, health and disease, stature, evidence for conflict, and physical activities reflected in bone morphology. The contrast between the quality of the later houses on the eastern mound compared with contemporary buildings to the west poses the possibility that there was an element of social inequality present in the Non Ban Jak community that might be evidenced in the human remains. Isotopic variations have not yet been studied, but identifying possible immigrants, and variations in diet over time and location in the site are planned. DNA has provided intimate insights into the population dynamics in the European sites referred to above. Most unfortunately, aDNA does not survive with any predictability in Southeast Asia, but new techniques, some centred on the dense petrous bone, offer some hope for the future.

Non Ban Jak is not currently occupied, and is open to extensive excavations. With time and resources, reconstructing the plan of a late Iron Age town is within our grasp. There is, of course, an impediment not matched in the European sites, where occupation spans were brief and stratigraphy shallow. At Non Ban Jak, houses accumulated as in a Near Eastern tell. Moreover, excavating the houses is a slow and meticulous exercise. The domestic aspect of later prehistory in the Mun Valley, if not across Southeast Asia as whole, is virtually unknown but pregnant with potential. Was there a rich suburb? Did the putative elite have a better diet? Did the less wealthy alone work in the rice fields, or labour in the construction of the moats and banks round their town site? Does the advent of residential burial signal the close bonds between corporate groups in the community and their ownership of assets? And what were the assets that generated wealth?

One of these, it is suggested, could well have been improved land for cultivating rice. The excavations at Non Ban Jak have incorporated the flotation of a sample of cultural material for organic remains. Clearly, rice dominates, but there are also weeds from species adapted to wet rice fields (Castillo 2014). A ploughshare was found in one of the eastern kilns. One of its wings was fractured and perhaps it was placed in the kiln to assist with repairs. The Mun Valley sites are ringed with broad moats. We know from remote sensing that the infrastructure of these Iron Age sites included canals and dams, as well as possible permanent rice field bunds (Parry 1992; Hawken 2011). When integrated, these have underwritten a model for an agricultural revolution involving permanent, ploughed and irrigated rice fields (Higham 2014). A second asset might well have been salt production. Many small, steeply sided mounds lie in the vicinity of the moated town sites. Excavation suggests that they accumulated through the production of salt (Rivett and Higham 2007). One potential means of obtaining wealth, the dependent production of ceramics for export, is not sustained at Non Ban Jak, where the evidence rather suggests a domestic mode for local consumption. 


\section{Summary}

The first four seasons of excavation at Non Ban Jak, a moated Iron Age town in the Mun Valley of Northeast Thailand, have uncovered two residential areas. Houses were constructed of clay walls and floors, strengthened with wooden foundations and wall posts, and probably clad in wattle and daub. The dead were interred by cutting graves through the house floors. The site was occupied during the late Iron Age, and continued into the Early Historic Period. It presents the potential to reconstruct the layout of a town plan, identify modes of production, and through the excellent survival of human remains, apply established and developing analytical techniques to the prehistoric people who lived there over a period of 15 to 20 generations.

\section{Acknowledgements}

I first met Peter Bellwood in June 1966, when he stopped me in King's Parade, Cambridge, and asked if I was going to accept a lectureship at the University of Otago. When I replied yes, he said that in that case, he would take up a post at the University of Auckland. I have greatly valued his friendship and major contributions to the Southeast Asian prehistory over the past 49 years, and it is a pleasure to be able to contribute to this Festschrift.

The first three seasons of excavation at Non Ban Jak were funded by a grant from the Australian Research Council for the programme 'From Paddy to Pura: the Origins of Angkor' to Dougald O'Reilly and Louise Shewan. The fieldwork was directed by Charles Higham, Rachanie Thosarat and Nigel Chang. The fourth season was funded by a grant to Associate Professor H. Buckley and Professor C.F.W. Higham from the University of Otago. I am most grateful to the National Research Council of Thailand and the Fine Arts Department for providing the necessary research permits. I am most grateful to Sian Halcrow and Nathan Harris for their identifying the age and sex of the prehistoric dead during the course of the fieldwork.

\section{References}

Bellwood, P., M. Oxenham, C.H. Bui N.T.K. Dung, A. Willis, C. Sarjeant, P.J. Piper, H. Matsumura, K. Tanaka, N. Beavan, T. Higham, Nguyen Quoc, Manh, Dang Ngoc Kinh, Nguyen Khanh Trung Kien, Vo Thanh Huong, Van Ngoc Bich, Tran Thi Kim Quy, Nguyen Phuong Thao, F. Campos, Y.I. Sato, Nguyen Lan Cuong and N. Amano. 2013. An Son and the Neolithic of Southern Vietnam. Asian Perspectives 50: 144-175. doi.org/10.1353/asi.2011.0007.

Brandt, G., C. Knipper N. Nicklisch, R. Ganslmeier, M. Klamm and K.W. Alt. 2014. Settlement burials at the Karsdorf LBK site, Saxony-Anhalt, Germany. Biological ties and residential mobility. In A. Whittle and P. Bickle (eds), Early Farmers: The View from Archaeology and Science. Proceedings of the British Academy 198: 95-114. doi.org/10.5871/bacad/9780197265758.003.0006.

Bùi, C.H., P.C. Thân and N. K. T. Kiên. 2012. Khảo Cổ Học Bà Rịa - Vũng Tảu Tứ Tiền Sử Dến Sơ Sử. (Bà Rịa - Vũng Tảu. From Prehistory to History). Hà Nội: Nhà Xuất Bản Khoa Học Xã Hội.

Castillo, C.C. 2014. The botanical remains. In C.F.W. Higham, J. Cameron, N. Chang, C.C. Castillo, D. O'Reilly, S.E. Halcrow, F. Petchey and L. Shewan (eds), The excavation of Non Ban Jak, Northeast Thailand - a report on the first three seasons. Journal of Indo-Pacific Archaeology 34: 37-39.

De Capitani, A and U. Leuzinger. 1998. Arbon-Bleiche 3: Siedlungsgeschichte, einheimische traditionen und fremdeinflüsse im Übergangsfeld zwischen Pfyner und Horgener Kultur. Jahrbuch der Schweizerischen Gesellschaft für Ur- und Frühgeschichte 81: 237-249. 
De Capitani, A., E. Deschler, U. Leuzinger, R. Marti-Grädel and J. Schibler. 2002. Die Jungsteinzeiliche Seeufersiedlung Arbon Bleiche 3: Funde. Frauenfeld: Kanton Thurgau.

Ebersbach, R. 2013. Houses, households, and settlements. Architecture and living spaces. In F. Menotti and A. O'Sullivan, (eds), The Oxford Handbook of Wetland Archaeology pp. 733-748. Oxford: Oxford University Press.

Eberschweiler, B., A. Hafner and C. Wolf. 2006. Unterwasserarchäeologie in der Schweiz: Bilanz un perspective aus den letzten 25 jahren. In A. Hafner, U. Niffeler and U. Ruoff (eds), Die Neue SichtUnterwasserarchäeologie und Geschichtsbild. Antiqua 40: 24-45. Basel: Multicolor Print.

Hawken, S. 2011. Metropolis of Ricefields: A Topographic Classification of a Dispersed Urban Complex. $\mathrm{PhD}$ thesis, University of Sydney, Sydney.

Higham C.F.W. 1966. Stock Rearing as a Cultural Factor in Prehistoric Europe. PhD thesis, University of Cambridge, Cambridge.

Higham C.F.W. 2014. From the Iron Age to Angkor: new light on the origins of a state. Antiquity 88: 822-835. doi.org/10.1017/S0003598X00050717.

- 2015. From site formation to social structure in prehistoric Thailand. Journal of Field Archaeology 40: 383-396. doi.org/10.1179/2042458214Y.0000000010.

Higham, C.F.W. and R. Bannanurag. 1990. The Excavation of Khok Phanom Di, a Prehistoric Site in Central Thailand. vol. I. The Excavation, Chronology and Human Burials. Report no. XLVII London: Society of Antiquaries of London, Research.

Higham, C.F.W. and A. Kijngam (eds). 2012. The Origins of the Civilization of Angkor. vol. V. The Excavation Ban Non Wat: The Iron Age, Summary and Conclusions. Bangkok: The Fine Arts Department of Thailand.

Higham, C.F.W. and F. Rispoli. 2014. The Mun Valley and Central Thailand in prehistory: integrating two cultural sequences. Open Archaeology 1: 2-28. doi.org/10.2478/opar-2014-0002.

McGrath, R. J. and W.E. Boyd. 2001. The chronology of the Iron Age 'moats' of Northeast Thailand. Antiquity 75: 349-360. doi.org/10.1017/S0003598X00061007.

O'Reilly, D.J.W. 1997. The discovery of clay-lined floors at an Iron Age site in Thailand - preliminary observations from Non Muang Kao, Nakhon Ratchasima Province. Journal of the Siam Society 85: $133-150$

Oxenham, M, P.J. Piper, P. Bellwood, Chi Hoang Bui, Khanh Trung, Kien Nguyen, Quoc Manh Nguyen, F. Campos, C. Castillo, R. Wood, C. Sarjeant, N. Amano, A. Willis, and J. Ceron. 2015. Emergence and diversification of the Neolithic in Southern Vietnam: insights from coastal Rach Nui. The Journal of Island and Coastal Archaeology 10(3): 309-338. doi.org/10.1080/15564894.2014.980473.

Parry, J. 1992. The investigative role of Landsat-TM in the examination of pre- and protohistoric water management sites in Northeast Thailand. Geocarto International 7(4): 5-24. doi. org/10.1080/10106049209354385.

Rivett, P. and C.F.W. Higham. 2007. The archaeology of salt production. In C.F.W. Higham, A. Kijngam and S. Talbot (eds), The Origins of the Civilization of Angkor. vol. 2. The Excavation of Noen U-Loke and Non Muang Kao, pp. 589-593. Bangkok: The Fine Arts Department.

White, J.C., and C.O. Eyre. 2010. Residential burial and the metal age of Thailand. In R. L. Adams and S. M. King (eds), Residential Burial: a Multiregional Exploration. Archaeological Papers of the American Anthropological Association 20: 59-78. doi.org/10.1111/j.1551-8248.2011.01028.x. 
This text is taken from New Perspectives in Southeast Asian and Pacific Prehistory, edited by Philip J. Piper, Hirofumi Matsumura and David Bulbeck, published 2017 by ANU Press, The Australian National University, Canberra, Australia. 